RESEARCH ARTICLE

\title{
Dispute Settlement on E- Commerce Contract: A Practical Analysis of Law
}

\author{
Firqotun Naziah \\ Indonesian Law and Tech Society \\ JI Kaliurang KM 5.5, Yogyakarta, INDONESIA \\ 凶firqotunnaziah711@yahoo.com
}

\section{a OPEN ACCESS}

Citation: Naziah, F. (2021).

Dispute Settlement on E-

Commerce Contract: A Practical Analysis of Law. Law Research Review Quarterly, 7(4), 473486.

https://doi.org/10.15294/Irrq.v $7 \mathrm{i} 4.48173$

Submitted : June 9, 2021

Revised : October 12, 2021

Accepted : November 1, 2021

(C) The Author(s)

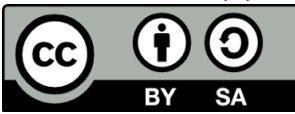

This work is licensed under a Creative Commons Attribution-ShareAlike 4.0 International License. All writings published in this journal are personal views of the authors and do not represent the views of this journal and the author's affiliated institutions.

\section{ISSN 2716-3415}

Law Research Review Quarterly published by Faculty of Law, Universitas Negeri Semarang, Indonesia. Published quarterly on February, May, August, and November.

\begin{abstract}
E-commerce is a form of trade which has its own characteristics that are cross-border trade, not to meet the seller and buyer, use media internet. The birth of Law No. 11 of 2008 is about Information and Electronic Transactions (ITE Law) seems to be the solution to provide protection for consumers. In the ITE Law has set the terms validity of ecommerce transactions, establishing the rights and obligations, prohibited acts, responsibility, legal protection, remedies, and dispute resolution in e-commerce transactions. This study analyzes the dispute settlement for e-commerce dispute in Indonesia.
\end{abstract}

Keywords: Consumer Protection, Legal Protection, Illegal Drugs, Law Enforcement

\section{INTRODUCTION}

The development of the internet world in Indonesia is quite proud, especially with the support of the government is very cooperative. The government also made a concrete step in developing the internet in Indonesia. Along with the development of science and technology increasingly rapidly, then the trade that was initially conducted in meet face-to-face and face-to-face between the parties also changed. The use of internet as a medium of trade continues to increase from year to year, this is due to various benefits obtained by companies and consumers by making transactions via the internet (Purbo \& Wahyudi, 2001). 
In Indonesia has started its use by some companies that is ecommerce or better known as E-Commerce. Ecommerce is basically a contact of trade transactions between sellers and buyers using the internet media. Ecommerce not only provides convenience for consumers, but this development allows manufacturers to market products that affect the cost and time savings. Implementation of buying and selling online in practice raises several problems such as Sellers are not responsible for delivering goods that have been ordered customers. As a consumer, we must be observant in buying a good. Usually in an e-commerce transaction there is an agreement between the business actor and the consumer. Buying and selling is one type of agreement set forth in the Civil Code, while ecommerce is basically a model of modern buying and selling transactions that implies technological innovations such as internet as a transaction medium. The will of the parties embodied in the agreement is the basis of the binding of a covenant, the will may be expressed in various ways both oral and written and binding on the parties with all its legal consequences (Hasibuan, 2007).

For those who do not take responsibility in accordance with the agreed agreement may be sued by the party who feels aggrieved to receive compensation. The importance of legal issues in the field of E-commerce is mainly in providing protection to the parties who make internet transactions. Therefore in 2008 Indonesia issued a special regulation governing internet transactions that is Law Number 11 of 2008 on Information and Electronic Transactions or abbreviated Act ITE (Republic of Indonesia, 2008, UU 11/2008). The electronic contract shall also have the same legal force as the conventional contract, which binds the parties as Article 18 paragraph 1 of the ITE Law which states that "electronic transactions poured into electronic contracts are binding on the parties". There is also a problem if when viewed from the civil law system, where the legitimate sale and purchase through the internet still can 
not be said to be valid in one of the valid terms of the agreement is the ability of the parties in making sale and purchase transactions. Because in buying and selling online a person does not know whether the person is proficient law as regulated in Article 1320 Civil Code (Fuady, 2002).

\section{METHOD}

The type of research used is descriptive research where descriptive research in accordance with the purpose of research. Besides using descriptive research also using qualitative methods (Purwaningsih, 2010). The focus of the research was conducted in order to obtain a general overview of the subject and situation under study as well aims to filter incoming information. In accordance with the rerumusan problems and goals that to be achieved, then the focus in this study are as follows:

1) An overview of the existing Sales System at Pastbrik Shop.

2) Implementation of e-commerce website at Pastbrik Shop that serves as a media of Promotion and Sales of Elektronies

Data sources can be obtained through two ways: (1) Primary Data Sources, and (2) Secondary Data Sources. Furthermore, according Sugiyono (2011: 244), data analysis is the process of searching and systematically compile data obtained from interviews, field notes, and documentation, by organizing data into categories, describing to units, synthesizing, organizing into patterns, choosing what is important and what to learn, and making conclusions so easily understood by yourself and others.

\section{RESULT AND DISCUSSION}

\section{A. The Legal Sale and Purchase Through Internet}

Buying and selling according to Civil Code article 1457 is an agreement with which one party advertise himself to submit an object and the other party to pay the price that has been promised. Whereas in article 1313 of the Civil Code an agreement is an act in which one or more persons commit 
themselves to one or more persons. If the buyer did the word/agreement agreed with the seller then there was the sale and purchase (Subekti, 2001). The terms of approval. The occurrence of the sale and purchase agreement is also stated in article 1458 of the Civil Code which reads "the sale and sale is considered to have occurred as soon as the people have reached agreement on the goods and the price, even though the goods have not yet been delivered and the price has not been paid." buying and selling through the internet, the parties involved in doing the legal relationship which is directed through a form of agreement or contract made electronically and in accordance with Article 1 paragraph 17 of the Information and Electronic Transaction Law (ITE) referred to as an electronic contract that is the agreement contained in the document electronic or other electronic media (Barkatullah \& Prasetyo, 2005). Business actors who offer goods or services electronically shall provide information on the terms of the contract, the manufacturer and the product completely and correctly. Based on the above understanding, can be drawn some elements of Ecommerce, namely:

1) There are trade contracts

2) The contract is executed by electronic media

3) The physical presence of the parties is not required

4) The contract occurs in the public network

5) The system is open, such as with internet or www

6) The contract is out of bounds, national jurisdiction

E-commerce Agreement known to two actors are merchants/business actors who make sales and buyer/ customer/consumer who acts as a buyer. In addition to business actors and consumers, in buying and selling transactions through internet media also involves providers as providers of internet services and banks as a means of payment. E-commerce transactions include many things, so to distinguish them need to be divided into types of Ecommerce. the types of transactions of an E-commerce 
activity as emphasized by Mertokusumo (2006), are as follows:

1) Business to Business

Transactions that occur between companies in this case, both buyers and sellers are a company and not an individual. Usually, these transactions are done because they already know each other, and the purchase transaction is done to establish cooperation between the company.

2) Business to Consumer

transactions between companies and consumers/ individuals. In this type of transactions are disseminated in general, and consumers who take the initiative to make transactions. Manufacturers must be prepared to receive a response from the consumer. Usually, the system used is a web system because this system is already commonly used among the community.

3) Consumer to Consumer

Sale and purchase transactions that occur between individuals and individuals who will sell each other goods.

4) Consumer to Business

Transactions that allow individuals to sell goods to the company.

a. Non-Business electronic Commerce

b. Intra-business (Organizational) Electronic

Commerce

The validity of the internet purchase agreement must have the same validity as the conventional agreement as long as it can be proven and fulfilled provisions in Article $1320 \mathrm{BW}$. The basis of legitimacy occurs when both agree and the word agreement between the buyer and the seller in communicating about the supply of goods and the selection of goods desired and both have agreed that the existence of the agreement. Validity itself occurs at the time of payment process in the agreement in which the payment can be paid 
directly or paid in stages from the agreed price. An Internet purchase agreement must also comply with the legitimate requirements of an agreement as contained in Article 1320 BW which can be proved and also not allowed (Maulana, Susilo, \& Riyadi, 2015).

Legal Requirement of Sale and Purchase Agreement through E-commerce Basically the legal requirement of sale and purchase agreement that has been contained in Article 1320 Civil Code, this can also be a reference to the legal terms of a sale and purchase agreement through e-commerce. Because e-commerce is also a buying and selling activity that the difference is made through online media. It's just in buying and selling through ecommerce done through the internet media that can accelerate, simplify and sale and purchase transactions. In the ITE Act also adds some other requirements, for example:

1) Good faith (Article 17, paragraph 2)

2) Provisions concerning the time of transmission and receipt of Information and / or Electronic Transaction (Article 8)

3) Using a reliable and secure Electronic System and responsible responsibility (Article 15)

In the e-commerce agreement, there is a bidding process and approval process of the type of goods purchased then the transaction between the seller and the buyer is completed. The seller receives the approval of the selected item, and the buyer receives confirmation that the order or choice of the item is known to the seller (Resiska, 2012). After the seller receives confirmation that the buyer has paid the price of the ordered goods, then the seller will proceed or send a confirmation to the shipping company to deliver the goods ordered to the buyer's address. After all the process is passed, where there are bidding, payment, and submission process. then the agreement is said to be completed entirely or the agreement expires (Hartanti, 2012). 


\section{B. Settlement of disputes in case of problems of sale and purchase implementation through internet (E- commerce)}

1) Problems arising in transactions via the Internet, among others:

a. Buyer Skills

Mentioned there are four terms of validity of a treaty that is: agreement between the two sides to bind themselves, the ability to make agreements, certain objects, and a lawful cause (Diana, Utomo, \& Nugraha, 2017). E-commerce is a modern trading method that does not bring together sellers and buyers, then for the occurrence of an agreement is difficult to know clearly when the agreement between the two parties occurred. In addition to the skills of both parties is also questionable because between the seller and the buyer does not meet directly it cannot be known clearly both parties are proficient or not according to the Act. Usually in general encountered in that case, how to cope with business actors on the website include age category or inside is allowed to enter the website or in the registration of personal data consumers listed such as ID or passport number which is expected to guarantee the ability of a consumer in the transaction (Al Arif, 2013).

Regarding a halal cause is also a problem in buying and selling transactions via the internet. Because the lawful in the Act is not violate morality and public order. The problem is that goods traded on the internet are diverse kinds of goods, and there are goods in a country that are traded but in certain countries there are goods that should not be traded. How to resolve this issue by enacting regulations prohibiting trade in goods in accordance with the positive law rules in Indonesia or entering into agreements between States on goods that may be traded in cyberspace. 
b. No agency guarantees the legitimacy of online stores

The company or online trading account in the online world that sells online stores is very easy to set up compared to establishing a company in the real world. [14] As the fact that the establishment of a company in the real world requires permission from officials / agencies concerned. But in establishing or building an online store in cyberspace just rent a place in cyberspace and create a web design online store on Internet Service Provider (ISP) then this online store can already operate like a store in the real world. Ease in making this online store that become problem for consumers who will buy products on the online store. The rise of cases of fraud against consumers such as fictitious online store, credit card number theft, and so forth. This problem can be overcome by creating an institution that serves to guarantee the legitimacy of the online store and give permission to operate in operation (Putra, 2014).

c. Transaction security issues related to legal certainty

Implications of the development of online buying and selling is felt there is a positive side and the negative side. The positive aspect that with the existence of trading on the internet through the online network can enhance the role and function of trade while providing an efficiency effect. Negative aspect is the issue of security in transactions using ecommerce media and juridically associated also with the guarantee of legal certainty. The issue of security in question in this aspect is the issue of message confidentiality, the problem of how to get the message transmitted wholly into the recipient's hand, the transactions' validity issue and the message authenticity issue to be evidence. 
d. The presence of unexplained consumers is clear

In view of the existence of transactions made in cyberspace, so it may be possible such a party to conduct transactions may be parties that are not legally allowed to take legal action. For example, the consumer who performs the transaction is aged under the terms stated in the terms of the transaction, or if there has been an agreement by both parties and when will be traced by the fictitious consumer (Rachmawati, 2015).

e. Diversity regarding existing law and legal jurisdiction binding on both sides

There is doubt about the existing law and legal jurisdiction that binds both parties conducting business or transactions. Where there are some who think or believe that the transaction is happening in cyberspace, the applicable law in cyberspace does not apply in practice although in some cases there are provisions that can be imposed in cyberspace. So, people assume that the law in cyberspace in the world of reality is different, when in fact the rule of the virtual world comes from everyday life that is usually governed by the rules.

Given the above facts, then there is a confusion about what laws can overcome problems that will arise in the future and existing ones. This is because the law that regulates about e-commerce business through the internet there is no conception and legislation is strong. The regulation that governs the evidentiary system to date has not been firmly established (Wahana \& Purliansyah, 2012).

2) Settlement of disputes in the sale and purchase transactions through the internet

In every job there are always 2 (two) kinds of legal subjects, each of which legal subjects have rights and obligations in mutual in the implementation of the agreement made. If one of the subjects does not 
implement what should be done in accordance with the agreement, then the act is said to be a default (Diaz \& Riyadi, 2014). Default has four kinds, namely: (a) not doing what it undertakes to do, (b) carrying out what is promised but too late, (c) carrying out what is promised but not as promised, (d) doing something according to the covenant should not be done. In most cases there is a default done by business actors such as late delivery of goods, wrong in sending products ordered goods, goods purchased not in accordance with information displayed or may also business actors who intentionally intend not to fulfill their obligations (Sanusi, 2001). The effort consumer to demand compensation can be done through:

a. Litigation

In accordance with Article 38 of the ITE Act which explains the parties may sue if in the conduct of electronic transactions harm, the other party. With the acknowledgment of electronic evidence as valid evidence in court as mentioned in Article 5 paragraphs 1, 2 and 3 of the ITE Act, evidence of evidence that may be used by consumers in court is evidence of transfer or proof of payment, SMS or message from social media that states the agreement to purchase, name, address, phone number and account number of business actor (Sulaiman, 2002).

b. Non litigation

In article 39 paragraph (2) of the ITE Act which explains that in addition to civil settlement settlements, the parties may settle disputes through arbitration, or other institutions (Hidayat, 2008). Settlement of disputes through non-litigation channels can be pursued through Non-Governmental Organizations, Directorate of Consumer Protection Disperindag, Consumer 
Dispute Settlement Agency (BPSK) and business actors themselves in a kinship. Each of these legal entities has a different approach in solving the existing case (Sautuninda, 2008).

\section{CONCLUSION}

Based on the results of the analysis of the discussion conducted in the writing of this law, it can be concluded as follows: The validity of the Internet purchase agreement must have the same validity as the conventional agreement insofar as it can be proved and comply with the provisions of Article 1320 BW. The basis of legitimacy occurs when both agree and the word agreement between the buyer and the seller in communicating about the supply of goods and the selection of goods desired and both have agreed that the existence of the agreement. Validity itself occurs at the time of payment process in the agreement in which the payment can be paid directly or paid in stages from the agreed price. An Internet purchase agreement must also comply with the legitimate requirements of an agreement as contained in Article 1320 BW which can be proved and not allowed. Settlement of disputes that occur in the online sale and purchase agreement if there is a disadvantaged party that can ask for compensation for default, because default (wanprestasi) has hurt the other party. Compensation for such default may be in the fulfillment of the agreement, the fulfillment of the agreement and the indemnity, ordinary compensation, cancellation of the agreement accompanied by indemnification. In the online sale and purchase agreement, the steps that can be taken include through Litigation under Article 38 paragraph (1) of the ITE Law and through non-litigation under Article 39 paragraph (2) of the ITE Law.

\section{DECLARATION OF CONFLICTING INTERESTS}

The Author declares that there is no potential conflict of interest in the research, authorship, and/or publication of this article. 


\section{FUNDING}

None

\section{ACKNOWLEDGEMENT}

None

\section{REFERENCES}

Al-Arif, M. N. R. (2013). Penjualan on-line berbasis media sosial dalam perspektif ekonomi Islam. Ijtihad: Jurnal Wacana Hukum Islam dan Kemanusiaan, 13(1), 33-48.

Arcanggih, J. C., \& Riyadi, K. (2014). Implementasi ECommerce Sebagai Media Promosi dan Penjualan Secara Elektronik (Studi Kasus pada Toko Jumbo Cell Bangil). Jurnal Administrasi Bisnis (JAB), 14(1).

Barkatullah, A. H., \& Prasetyo, T. (2005). Bisnis E-Commerce Studi Sistem Keamanan dan Hukum di Indonesia. Yogyakarta: Pustaka Pelajar.

Firdayanti, R. (2012). Persepsi risiko melakukan eCommerce dengan kepercayaan konsumen dalam membeli produk fashion online. Journal of Social and Industrial Psychology, 1(1).

Fitria, T. N. (2017). Bisnis jual beli online (online shop) dalam Hukum Islam dan Hukum Negara. Jurnal Ilmiah Ekonomi Islam, 3(01), 52-62.

Fuady, M. (2002). Pengantar Hukum Bisnis. Bandung: Citra Aditya Bakti.

Haryanti, S. (2010). Rancang Bangun Sistem Informasi ECommerce Untuk Usaha Fashion Studi Kasus Omah Mode Kudus. Speed-Sentra Penelitian Engineering dan Edukasi, 3(1).

Hasibuan, Z. A. (2007). Metodologi Penelitian pada Bidang Ilmu Komputer dan Teknologi Informasi. Jakarta: Infonesia.

Hidayat, T. (2008). Panduan Membuat Toko Online dengan E-Commerce. Jakarta: Mediakita.

Maulana, S. M., Susilo, H., \& Susilo, H. (2015). Implementasi e-commerce sebagai media penjualan online (studi kasus pada toko pastbrik kota malang). Jurnal Administrasi Bisnis, 29(1), 1-9.

Mertokusumo, S. (2006). Penemuan Hukum Sebuah Pengantar. Yogyakarta: Liberty.

Purbo, O. W., \& Wahyudi, A. A. (2001). Mengenal eCommerce. Jakarta: Elex Media Komputindo. 
Purwaningsih, E. (2010). Hukum Bisnis. Jakarta: Ghalia Indonesia.

Putra, S. (2014). Perlindungan Hukum Terhadap Konsumen Dalam Transaksi Jual-Beli Melalui ECommerce. Jurnal Ilmu Hukum, 5(2), 197-208.

Rachmawati, E. N. (2015). Akad jual beli dalam perspektif fikih dan praktiknya di pasar modal Indonesia. Al'Adalah, 12(2), 785-806.

Republic of Indonesia. (2008). Undang-Undang Nomor 11 Tahun 2008 Tentang Informasi, Transaksi dan Elektronik

Sanusi, M. A. (2001). E-Commerce Hukum dan Solusinya. Jakarta: Mizan Grafik Sarana.

Subekti, S. (2001). Pokok-Pokok Hukum Perdata. Jakarta: Intermasa.

Sulaiman, R. (2002). Cyber Crimes: Perspektif E-Commerce Crime. Jakarta: PT. Deltacitra Grafindo.

Supono, S., \& Wahyudi, B. (2019). Perancangan Sistem Pembelanjaan Secara Online (E-Commerce) untuk Pasar Swalayan. Jurnal Ilmiah Informatika Komputer, 23(1), 21-35.

Wahana, A., \& Purliansyah, I. (2012). Pembangunan ECommerce (Penjualan Online) Pada Turpez Shop. Jurnal Computech E Bisnis, 6(1), 27-33. 


\section{IN THE COMMERCE}

\section{OF LANGUAGE USE}

\section{ONLY COIN OF GOLD}

\section{AND SILVER}

\section{JOSEPH JOUBERT}

PICTUREQUOTES . com 